\title{
Mitochondrial Number in Oligo and Azoospermia Male Patients
}

\author{
Haneen E. Hashim ${ }^{1}$; Mowafak K. Hasan ${ }^{2}$ \\ ${ }^{1,2}$ University of Mosul/College of Sciences/Dep. Of Biology \\ "Corresponding author. Email: mufsbio62@uomosul.edu.iq
}

\begin{abstract}
Male infertility causes present in about 50\% of the infertility cases, the standard quantity and quality of semen ejaculated during each coitus averages about 2-4 milliliters and every milliliter of seminal fluid contains contain about 100-120 million sperm/ $\mathrm{ml}$. When the number of sperm in each milliliter drops below 20 million; the person is probably having infertile problem. Forty-five semen samples were collected from males with ages ranged from 25 to 45 years. The samples were divided into three groups each consists of 15 males. The first group represent control group included 15 apparently health fertile subject. The second group contain 15 patients with oligospermia with sperm count $\leq 20$ million sperm $/ \mathrm{ml}$. The results of this table display there were significant variation in count between control group (54 \pm 19.7$)$ in comparison to oligo group $(9.2 \pm 7.49)$ and the $\mathrm{p} \leq 0.000$. there is a significant variation in active motility between control group $(37.6 \pm 15.1)$ in comparison to oligo group $(18.0 \pm 10.1)$, we can note a variation in normal morphology between control group (69.2 \pm 8.0$)$ and oligo group $(60 \pm 9.6)$ but it is less than the variation between count and the active motility as we mentioned above, whereas the p-value $\leq(0.01)$. There was significant reduction in both seminal pyruvate and Lactate in Azoospermia patients in comparison to control group $\mathrm{p}<0.01$ figure 1 and 2 respectively. In conclusion; Mitochondrial copy number significantly related to fertility status in males
\end{abstract}

Keywords: mitochondria copy number, infertility, Azoospermia, oligospermia.

\section{INTRODUCTION}

Infertility is a world-wide heath problem affecting up to $15 \%$ of married people in the world (Dohle, et al., 2020). Infertility is the inability to have conception after one year of intercourse despite of unprotected sexual activity (Jungwirth et al., 2017).

Male infertility causes present in about $50 \%$ of the infertility cases, the standard quantity and quality of semen ejaculated during each coitus averages about 2-4 milliliters and every milliliter of seminal fluid contains contain about 100-120 million sperm/ $\mathrm{ml}$. When the number of sperm in each milliliter drops below 20 million; the person is probably having infertile problem. Mitochondria are micro-organelle that responsible for many biological function as generating energy, $\mathrm{Ca}$ homeostasis and apoptosis. The number and shape of mitochondria vary according to the cell types, as the number increase in cells that required high energy like muscles and sperm flagella (Perchec et al. 1995; Gronczewska et al.,2019).

Sperms contain mitochondria copy number less than in oocyte in human cells. The Oxidative phosphorylation proposed to be crucial determinant of the motility of sperms (Singh Rajender a.et al ,2010). Previous studies propose that fertilizing capacity related to characteristics of progressive motility of sperms and the sperms motility depending on the content of ATP (Christen et al. 1987; Perchec et al. 1995; Gronczewska .et al ,2019).

Extracellular pyruvate consumed by sperms is turn to lactate even under aerobic conditions. This reaction is catalyzed by Lactate dehydrogenase (LDH) within the final step of carboxylic acid fermentation which associated with production of NAD+ from NADH, 
which is important for the rapid glycolysis. The aim of this work was to study the changes in mitochondrial copy number between patients have oligo and Azoospermia in Mosul.

\section{MARTIALS AND METHODS}

Forty-five semen samples were collected from males with ages ranged from 25 to 45 years. The samples were divided into three groups each consists of 15 males. The first group represent control group included 15 apparently health fertile subject. The second group contain 15 patients with oligospermia with sperm count $\leqslant 20$ million sperm / $\mathrm{ml}$. The third group contain patients with azoospermia. The experiment carried out from August 2019 to January 2021 under ethical approval No. in 2020. Semen samples were handled using CASA method (Computer Assisted Semen Analysis). The Casa devices maintain a temperature of 37 , because sperm motility is susceptible to temperature, sperms concentration and the characteristics of Motility can be assessed in undiluted semen. Sperm motility can be evaluating in samples with sperm concentrations between $2 \times 106$ per $\mathrm{ml}$ and $50 \times 106$ per ml (Garrett et al., 2003). The levels of pyruvate and L- Lactate were determined according cayman assay kit (Egras, et al., 2002, chung, et al., 2006) (Galdden .L.B. et al ., 2004 , passarella ,S.de. et al., 2008).

Sperm DNA isolated according Add Bio kit then DNA concentration determined by Nano-drop system samples contain $100 \mathrm{ng} / \mu \mathrm{l}$. The qPCR method has been used to detect accurate quantification of ND1 copy number gene expression

\begin{tabular}{|c|c|c|}
\hline Gene & Sequence & Size \\
\hline $\begin{array}{c}\text { Homo } \\
\text { sapiens } \\
\text { GAPDH }\end{array}$ & $\begin{array}{c}\text { F CGGGTCTTTCAGTCGTATG } \\
\text { CTGTTTCTGGGGACTAGGGG }\end{array}$ & \\
& & \\
\hline $\begin{array}{c}\text { Homo } \\
\text { sapiens } \\
\text { mt-ND1 }\end{array}$ & $\begin{array}{c}\text { F ATTATCGCCCCAACCCTCTC } \\
\text { GCTCGTAGGGCTCCGAATAG }\end{array}$ & 191 \\
& & \\
\hline
\end{tabular}

Data were present as mean \pm SD. ANOVA and paired t-Test were used to define the degree of significance at $\mathrm{p} \leqslant 0.05$. Person correlation was used to study the correlation between the measured parameters.

\section{RESULTS}

The results of this table display there were significant variation in count between control group $(54 \pm 19.7)$ in comparison to oligo group $(9.2 \pm 7.49)$ and the $\mathrm{p} \leqslant$ 0.000 . there is a significant variation in active motility between control group $(37.6 \pm 15.1)$ in comparison to oligo group $(18.0 \pm 10.1)$, we can note a variation in normal morphology between control group (69.2 \pm 8.0$)$ and oligo group $(60 \pm 9.6)$ but it is less than the variation between count and the active motility as we mentioned above, whereas the p-value $\leqslant(0.01)$. On the other hand, there is no significant variation between control group and oligo group. when we compare the volume between these two groups, whereas the $\mathrm{p}$-vale $\leqslant$ (0.7), as show in Table (1).

Table 1. Seminal fluid analysis results for fertile and Oligospermia

\begin{tabular}{|l|l|l|l|}
\hline Parameters & Control & Oligo & $p$-value \\
\hline Volume (ml) & $3.6 \pm 1.29$ & 3.40 .9 & 0.7 \\
\hline Count million/ml & $54 \pm 19.7$ & $\begin{array}{l}9.2 \\
7.49\end{array}$ & $0.000^{* * *}$ \\
\hline $\begin{array}{l}\text { Active } \\
\text { progressive \% }\end{array}$ & $37.6 \pm 15.1$ & 18.0 & $0.000^{* * *}$ \\
\hline $\begin{array}{l}\text { Normal } \\
\text { morphology\% }\end{array}$ & $69.2 \pm 8.0$ & 609.0 & $0.010^{*}$ \\
\hline
\end{tabular}

In table (2) below, we can note there are zero value in pvalue when we compare between control group (54 \pm 19.7) and Azoospermia (0) in case of count, active, and normal morphology, and there is a significant variation in case of volume between these two groups, and the $p$ $\leqslant 0.000$.

In table (3), there were highly significant reduction in count, sperm activity, volume and morphology between oligo group and azoospermia. were oligo=9.2 \pm 7.49 , Azoospermia $=0$ respectively at $p \leqslant 0.000$. Activity of sperm percentage also showed significant re oligo $=18.0$ \pm 10.1 , Azoospermia $=0) \mathrm{p} \leqslant(0.000)$ and volum(oligo $=3.4 \pm 0.9$, Azoospermia $=2.1 \pm 0.4)$ and the $p$-value $\leqslant(0.000)$, but , ther s zero p-value when we compare between the two group in case of normal morphology as shown in the table (3). 
Table 2. Seminal fluid analysis results for fertile and Azoospermia

\begin{tabular}{|l|l|l|l|}
\hline parameters & Oligo & $\begin{array}{l}\text { Azoosp } \\
\text { ermia }\end{array}$ & p-value \\
\hline Volume(ml) & $3.4 \pm 0.9$ & $2.1 \pm 0.4$ & 0.000 \\
\hline Count million/ml & $\begin{array}{l}9.2 \pm \\
7.49\end{array}$ & 0 & 0.000 \\
\hline $\begin{array}{l}\text { Active progress } \\
\%\end{array}$ & $\begin{array}{l}18.0 \pm \\
10.1\end{array}$ & 0 & 0.000 \\
\hline $\begin{array}{l}\text { Normal } \\
\text { morphology } \%\end{array}$ & $60 \pm 9.6$ & 0 & 0.000 \\
\hline
\end{tabular}

Table 3. Seminal fluid analysis results for Oligo and Azoospermia

\begin{tabular}{|l|l|l|l|}
\hline parameters & Control & Azoospermia & $p$-value \\
\hline Volume (ml) & $\begin{array}{l}3.6 \pm \\
1.29\end{array}$ & $2.1 \pm 0.4$ & $0.000 * * *$ \\
\hline $\begin{array}{l}\text { Count } \\
\text { (million/ml) }\end{array}$ & $\begin{array}{l}54 \pm \\
19.7\end{array}$ & 0 & 0.000 \\
\hline $\begin{array}{l}\text { Active } \\
\text { progressive (\%) }\end{array}$ & $\begin{array}{l}37.6 \pm \\
15.1\end{array}$ & 0 & 0.000 \\
\hline $\begin{array}{l}\text { Normal } \\
\text { morphology(\%) }\end{array}$ & $\begin{array}{l}69.2 \pm \\
8.0\end{array}$ & 0 & 0.000 \\
\hline
\end{tabular}

There was significant reduction in both seminal pyruvate and Lactate in Azoospermia patients in comparison to control group $\mathrm{p}<0.01$ figure 1 and 2 respectively.

\section{DISCUSSION}

The corner stone for evaluation of the man fertility remains semen fluid analysis; and the conventional parameters given most importance have been the concentration, progressive motility, and normal morphology of sperm in the ejaculate (Lewis, 2007).

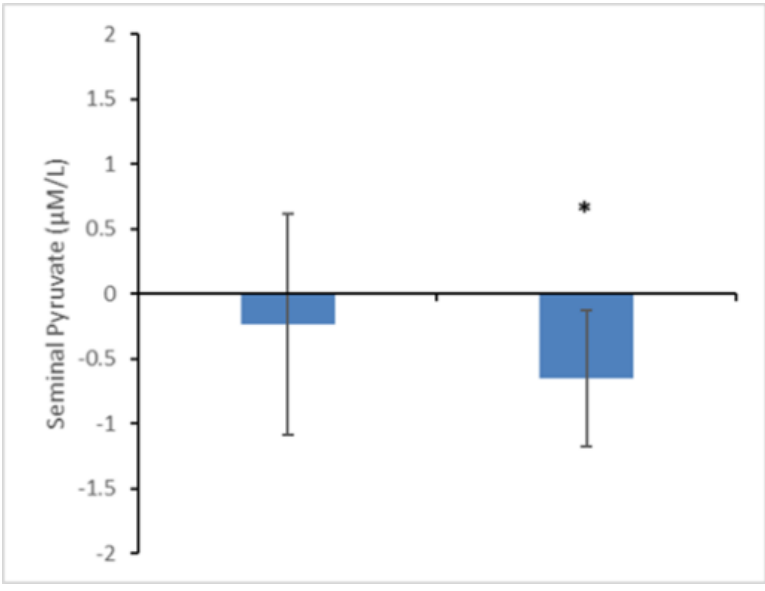

Figure 1. Normalized Seminal Fluid Pyruvate in both Oligo and Azoospermia

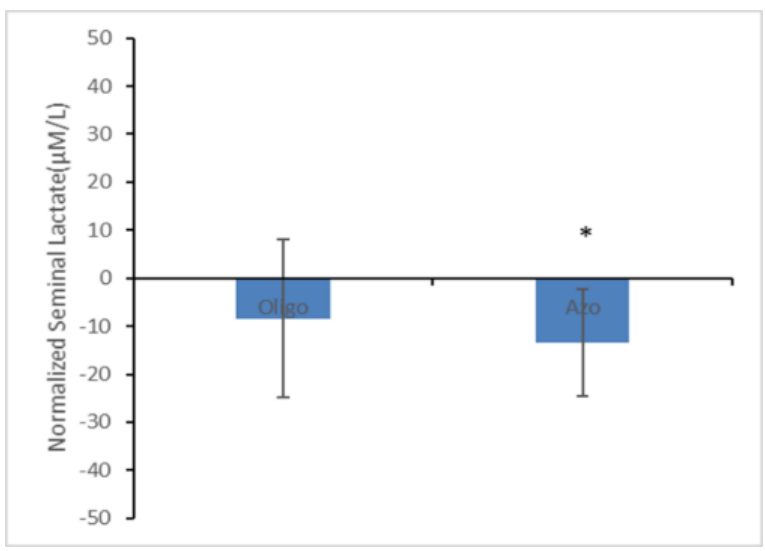

Figure 2. Normalized Seminal Fluid Lactate in both Oligo and Azoospermia

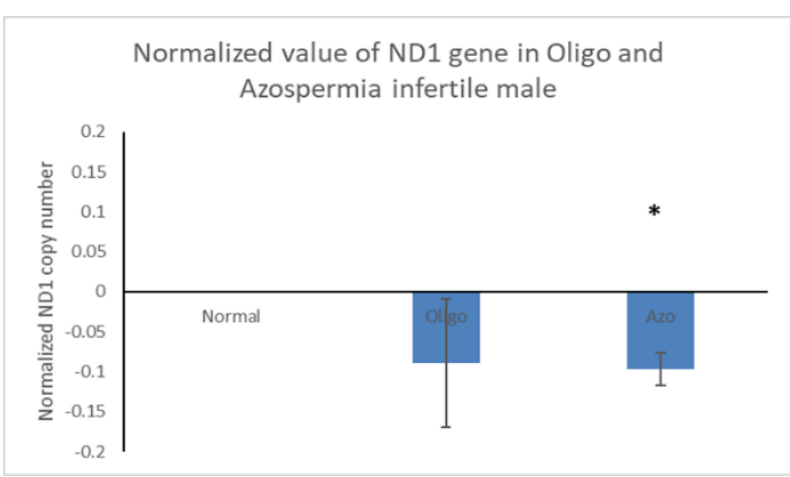

Figure 3. Normalized value of ND1 gene in Oligo and azoospermia in infertile male

Although it gives some quantitative and qualitative information about the sperm sample, recent insight into the molecular biology and genetics of the sperm cell have demonstrated that concentration, morphology and motility alone are not the only grounds upon which sperm should be evaluated (Marchesi and Feng, 2007). 
This study designed to explain the correlation between mitochondrial copy number and infertility, the results of this work showed that in both oligospermia and azoospermia groups; mitochondrial copy number significantly reduced than the copy number and control groups. This finding goes with other researchers that found that mtDNA copy number associated with low sperm count, motility, concentration and morphology (May-Panloup et al., 2003; Song and Lewis, 2008; Zhang et al., 2016) (Wu, H., et al.,2019). Also Song and his group, indicate that significant decrease in mtDNA integrity were observed in the spermatozoa samples from patients with abnormal semen parameters compared to the patients with normal semen parameters. The integrity and copy number of mtDNA were significantly correlated with sperm count Song, G. J.et al (2008).

The probability of the presence of mtDNA in the azoospermia is likely to residual contamination of somatic cells in the final sperm population could affect the accurate quantification of sperm mtDNA measures. According to Chen et al., Comparing with normozoospermia, patients and oligoa then azoospermia had a significant decrease in cell-free mtDNA copy number (Chen, Y. et al., 2018).

Also, in the present study, seminal lactate content in the control group was higher than it is in oligo and Azoospermia groups and that goes with the finding of Mumcu et al., who reported that the level of lactate was significantly decreased in patients with OAT compared to the controls. reported decreased levels of lactate and citrate, in oligozoospermic patients compared to the normo and azoospermia men (Mumcu et al, 2020).

\section{CONCLUSION}

In conclusion; Mitochondrial copy number significantly related to fertility status in males. There was significant reduction in both seminal pyruvate and Lactate in Azoospermia patients in comparison to control group.

\section{REFERENCES}

[1] Dohle, G. R., Colpi, G. M., Hargreave, T. B., Papp, G. K., Jungwirth, A., Weidner, W. E. A. U., \& EAU Working Group on Male Infertility. (2005). EAU guidelines on male infertility. European urology, 48(5), 703-711.

A.Jungwirth(chair),T.Diemer (Vice-chair), Z.kopa , C.Krausz and H.Tournaye . EAU Guidelines on male infertility. EAU, urol 2017

Ilieva, I., Sainova, I., \& Zvetkova, E. (2017). Sperm mitochondria-associated male infertility: sperm quality defects and mitochondria (mtDNA) anomalies. Acta morphologica et anthropologica, 24, 3-4.

Pena, F. J., Plaza Davila, M., Ball, B. A., Squires, E. L., Martin Munoz, P., Ortega Ferrusola, C., \& Balao da Silva, C. (2015). The impact of reproductive technologies on stallion mitochondrial function. Reproduction in Domestic Animals, 50(4), 529. 537.

Christen, R., GATTI, J. L., \& Billard, R. (1987). Trout sperm motility: the transient movement of trout sperm is related to changes in the concentration of ATP following the activation of the flagellar movement. European Journal of Biochemistry, 166(3), 667-671.

Perchec, G., Jeulin, C., Cosson, J., Andre, F., \& Billard, R. (1995). Relationship between sperm ATP content and motility of carp spermatozoa. Journal of cell science, 108(2), 747-753.

Rajender, S., Rahul, P., \& Mahdi, A. A. (2010). Mitochondria, spermatogenesis and male infertility. Mitochondrion, 10(5), 419-428.

Gronczewska, J., Niedźwiecka, N., Grzyb, K., \& Skorkowski, E. F. (2019). Bioenergetics of fish spermatozoa with focus on some herring (Clupea harengus) enzymes. Fish physiology and biochemistry, 45(5), 1615-1625.

Storey, B. T. (1978). Effect of lonophores and inhibitors and uncouplers of oxidative phosphorylation on sperm respiration. Archives of andrology, 1(2), 169-177.

McCommis, K. S., \& Finck, B. N. (2015). Mitochondrial pyruvate transport: a historical perspective and future research directions. Biochemical journal, 466(3), 443-454.

Hereng, T. H., Elgstøen, K. B. P., Cederkvist, F. H., Eide, L., Jahnsen, T., Skålhegg, B. S., \& Rosendal, K. R. (2011). Exogenous pyruvate accelerates glycolysis and promotes capacitation in human spermatozoa. Human Reproduction, 26(12), 32493263.

Nowicka-Bauer, K., Lepczynski, A., Ozgo, M., Kamieniczna, M., Fraczek, M., Stanski, L., ... \& Kurpisz, M. K. (2018). Sperm mitochondrial dysfunction and oxidative stress as possible reasons for isolated asthenozoospermia. Journal of Physiology and Pharmacology, 69(3).

De Jonge, C. (2005). Biological basis for human capacitation. Human Reproduction Update, 11(3), 205-214. 
Ferramosca, A., \& Zara, V. (2014). Bioenergetics of mammalian sperm capacitation. BioMed research international, 2014.

Ferramosca, A., \& Zara, V. (2014). Bioenergetics of mammalian sperm capacitation. BioMed research international, 2014.

Emanuël STAS. (2016 - 2017). Role of pyruvate, lactate and glucose in stallion sperm motility under capacitating conditions. GHENT UNIVERSITY FACULTY OF VETERINARY MEDICINE Academic year 2016 - 2017.

Emanuël STAS. Role of pyruvate, lactate and glucose in stallion sperm motility under capacitating conditions (2016-2017).

Du Plessis S.S., Agarwal A., Mohanty G., van der Linde M. (2015). Oxidative phosphorylation versus glycolysis: what fuel do spermatozoa use? Asian Journal of Andrology, 17, 230-235

Nowicka-Bauer, K., Lepczynski, A., Ozgo, M., Kamieniczna, M., Fraczek, M., Stanski, L., ... \& Kurpisz, M. K. (2018). Sperm mitochondrial dysfunction and oxidative stress as possible reasons for isolated asthenozoospermia. Journal of Physiology and Pharmacology, 69(3).

Hildyard JC \& Halestrap AP. (2003) Identification of the mitochondrial pyruvate carrier in Saccharomyces cerevisiae. Biochem J 374, 607611.

Halestrap AP, Scott RD \& Thomas AP. (1980) Mitochondrial pyruvate transport and its hormonal regulation. Int J Biochem 11, 97-105

Passarella S, de Bari L, Valenti D, Pizzuto R, Paventi G \& Atlante A. (2008) Mitochondria and L-lactate metabolism. FEBS Lett 582, 3569-3576.

Goldberg E. (1963) Lactic and malic dehydrogenases in human spermatozoa. Science 139, 602-603.

Blanco A \& Zinkham WH. (1963) Lactate dehydrogenases in human testes. Science 139, 601-602.

Burgos C, Maldonado C, Gerez de Burgos NM, Aoki A \& Blanco A. (1995) Intracellular localization of the testicular and sperm-specific lactate dehydrogenase isozyme C4 in mice. Biol Reprod 53, 84-92.

Alvarez JG \& Storey BT. (1984) Assessment of cell damage caused by spontaneous lipid peroxidation in rabbit spermatozoa. Biol Reprod 30, 323-331.

Gallina FG, Gerez de Burgos NM, Burgos C, Coronel CE \& Blanco A. (1994) The lactate/pyruvate shuttle in spermatozoa: operation in vitro. Arch Biochem Biophys 308, 515-519.

P. Piomboni, R. Focarelli, A. Stendardi, A. Ferramosca, And V. Zara. The role of mitochondria in energy production for human sperm motility (2011).wiley online library,international journal of andrology Volume35, Issue2 April 2012 Pages 109-124

Yusnita, Y., Norsiah, M. D., \& Rahman, A. J. (2010). Mutations in mitochondrial NADH dehydrogenase subunit 1 (mtND1) gene in colorectal carcinoma. The Malaysian journal of pathology, 32(2), 103 110.

Hunte, C., Zickermann, V., \& Brandt, U. (2010). Functional modules and structural basis of conformational coupling in mitochondrial complex I. Science, 329(5990), 448-451.

Mao, G. H., Huang, X. H., Geng, X. J., Li, Q., Zhang, Y., \& Dou, Q. (2020). Correlation between sperm mitochondrial ND5 and ND6 gene variations and total fertilisation failure. Archives of medical science: AMS, 16(3), 692.

Fromm, S., Senkler, J., Eubel, H., Peterhänsel, C., \& Braun, H. P. (2016). Life without complex I: proteome analyses of an Arabidopsis mutant lacking the mitochondrial $\mathrm{NADH}$ dehydrogenase complex. Journal of experimental botany, 67(10), 3079-3093.

Abd Elrahman, M. M., Hassanane, M. S., Alam, S. S. Hassan, N. H., \& Amer, M. K. (2021). Assessment of correlation between asthenozoospermia and mitochondrial DNA mutations in Egyptian infertile men. Journal of Genetic Engineering and Biotechnology, 19(1), 1-15.

Egras, A.M., Hamilton,W.R.,Lenz, T.L., et al (2011). An evidence _ based review of fat modifying supplemental weight loss products.Journal of obesity, 1-7 .

Chung, C,-K., wang ,T.-J.,Yeung ,C-Y., et al (2006).interference and blood sample preparation for pyruvate enzymatic assay.Clin Biochm. 39, 74 77

Gladden .L.B.(2004). Lactate metabolism: Anew paradigm for the third millennium. J .physiol.558(1)

Passarella, S., de Bari,L., Daniela,V., et al. (2008).mitochondri and L-lactate metabolism. FEBS 1.ett.582, 3569-3576

Wu, H., Huffman, A. M., Whitcomb, B. W., Josyula, S., Labrie, S., Tougias, E., ... \& Pilsner, J. R. (2019). 
Sperm mitochondrial DNA measures and semen parameters among men undergoing fertility treatment. Reproductive biomedicine online, 38(1), 66-75.

May - Panloup, P., Chrétien, M. F., Savagner, F., Vasseur, C., Jean, M., Malthiery, Y., \& Reynier, P. (2003). Increased sperm mitochondrial DNA content in male infertility. Human Reproduction, 18(3), 550-556.

Song, G. J., \& Lewis, V. (2008). Mitochondrial DNA integrity and copy number in sperm from infertile men. Fertility and sterility, 90(6), 2238-2244.

Zhang, G., Wang, Z., Ling, X., Zou, P., Yang, H., Chen, Q., ... \& Ao, L. (2016). Mitochondrial biomarkers reflect semen quality: results from the MARCHS study in Chongqing, China. PLoS One, 11(12), e0168823.

Chen, Y., Liao, T., Zhu, L., Lin, X., Wu, R., \& Jin, L. (2018). Seminal plasma cell-free mitochondrial DNA copy number is associated with human semen quality. European Journal of Obstetrics \& Gynecology and Reproductive Biology, 231, 164168.

Mumcu, A. K. I. N., Karaer, A. B. D. U. L. L. A. H., Dogan, B. E. R. A. T., \& Tuncay, G. (2020). Metabolomics analysis of seminal plasma in patients with idiopathic Oligoasthenoteratozoospermia using high resolution NMR spectroscopy. Andrology, 8(2), 450-456.

Lewis, S. (2007): Is sperm evaluation useful in predicting human fertility? Reprod., 134: 31-40

Marchesi, D. E. and Feng, H. L. (2007): Sperm DNA Integrity From Sperm to Egg. J. of Androl., 28, 4: 481-489.
[9] A. Pnueli, In transition from global to modular temporal reasoning about programs, in: K.R. Apt (Ed.), Logics and Models of Concurrent Systems, Springer, Berlin, Heidelberg, 1984, pp. 123-144. DOI: https://doi.org/10.1007/978-3-642-82453-1_5

[10] B. Meyer, Applying "Design by Contract", Computer 25(10) (1992) 40-51. DOI: https://doi.org/10.1109/2.161279

[11] S. Bensalem, M. Bogza, A. Legay, T.H. Nguyen, J. Sifakis, R. Yan, Incremental component-based construction and verification using invariants, in: Proceedings of the Conference on Formal Methods in Computer Aided Design (FMCAD), IEEE Press, Piscataway, NJ, 2010, pp. 257-256.

[12] H. Barringer, C.S. Pasareanu, D. Giannakopolou, Proof rules for automated compositional verification through learning, in Proc. of the 2nd International Workshop on Specification and Verification of Component Based Systems, 2003.

[13] M.G. Bobaru, C.S. Pasareanu, D. Giannakopoulou, Automated assume-guarantee reasoning by abstraction refinement, in: A. Gupta, S. Malik (Eds.), Proceedings of the Computer Aided Verification, Springer, Berlin, Heidelberg, 2008, pp. 135-148. DOI: https://doi.org/10.1007/978-3540-70545-1_14 